\title{
Pinpointing single metal atom anchoring sites in carbon for oxygen reduction: Doping sites or defects?
}

\author{
Cai Zhang a, Wei Zhang a,b,c,*, Weitao Zheng a,\#
}

Enabling the conversion of chemical energy of fuels directly into electricity without combustion, fuel cells are arousing great interest in both academia and industry. A typical case is the proton exchange membrane fuel cell (PEMFC), already commercialized by automobile giants. For mass popularization, however, three major criteria must be balanced: performance, durability and cost. The electrocatalysts used in both the anode and cathode are the kernel of PEMFCs, being essential for efficient operation. First in the firing-line is the oxygen reduction reaction (ORR) at the cathode, which is normally very sluggish: over six orders of magnitude slower than the anode hydrogen oxidation reaction (HOR) [1]. Thus, considerable efforts have been made to improve the cathode ORR. Identifying the main active sites is key to the design of optimum materials for enhanced ORR. Considering the complex balance of preparation, performance and cost, the active sites of metal-nitrogen-carbon (M-N-C) catalysts are particularly promising. Coupled with the single metal atom (SMA) catalysts [2-5], two excellent M-N-C catalysts were recently reported [6,7]. New insights were thereby gained into the delicate architecture of carbon-based SMA catalysts for ORR.

One of the best ORR catalysts is known to be Pt. Intensive efforts have focused on downsizing and alloying of Pt to maximize the exposure of active sites. A recent work reported that Pt single atoms supported on nitrogen (N)-doped carbon black exhibit excellent ORR activity and fuel cell performance [6]. Pt supported on $\mathrm{N}$-doped carbon $\left(\mathrm{Pt}_{1}-\mathrm{N} / \mathrm{C}\right)$ was found to consist entirely of highly dispersed individual $\mathrm{Pt}$ atoms, which differs from $\mathrm{Pt}$ supported on pure carbon $\left(\mathrm{Pt}_{1} / \mathrm{C}\right)$, where some Pt nanoparticles (NPs) and clusters were also observed. This indicates that doped N atoms can anchor single Pt atoms. Such anchoring prevents their aggregation into NPs. Additionally, the strong interaction between $\mathrm{N}$ and Pt prevents the oxidation of $\mathrm{Pt}$ atoms in air. Thus, the ORR activity of $\mathrm{Pt}_{1}-\mathrm{N} / \mathrm{C}$ was demonstrated to be superior to $\mathrm{Pt}_{1} / \mathrm{C}$ and $\mathrm{N}$-doped carbon, and close to commercial $\mathrm{Pt} / \mathrm{C}$. Particularly, $\mathrm{Pt}_{1}-\mathrm{N} / \mathrm{C}$ exhibits high tolerance to methanol or carbon monoxide, attributed to its stronger adsorption of $\mathrm{O}_{2}$ than $\mathrm{CO}$ according to theoretical calcula- tions. Meanwhile, a density functional theory (DFT) calculation confirmed that $\mathrm{Pt}_{1}$ atoms can be strongly trapped by pyridinic $\mathrm{N}$ sites, which favors the dispersion of Pt single atoms on carbon and the durability of $\mathrm{Pt}_{1}-\mathrm{N} / \mathrm{C}$ for ORR. The mechanism of ORR catalyzed by this material was analyzed (Fig. 1(a)). The adsorption mode of $\mathrm{O}_{2}$ was found to be a side-on configuration on the graphene-supported single $\mathrm{Pt}$ atom (g-Pt $1-\mathrm{N} / \mathrm{C}$ ). The $\mathrm{O}-\mathrm{O}$ bond on $\mathrm{g}-\mathrm{Pt}_{1}-\mathrm{N} / \mathrm{C}$ is longer than in $\mathrm{O}_{2}$ adsorbed on bulk $\mathrm{Pt}$ NP-based active sites $\left(\mathrm{g}-\mathrm{Pt}_{1} / \mathrm{C}\right)$, indicating the relative ease of breaking the $0-0$ bond on Pt single atoms compared with the bulk. Free energy calculations reveal that the ORR activity of $\mathrm{g}-\mathrm{Pt}_{1}-\mathrm{N} / \mathrm{C}$ is close to conventional $\mathrm{Pt} / \mathrm{C}$ catalysts, attributed to the synergistic effect between Pt single atom centers and pyridinic N. The strong oxidation resistance of $g-\mathrm{Pt}_{1}-\mathrm{N} / \mathrm{C}$ was also demonstrated by calculating the formation energies and Bader charges of oxidized g- $\mathrm{Pt}_{1}$ sites, $\mathrm{g}-\mathrm{Pt}_{1}-\mathrm{N}$ sites and the entire system. Moreover, the small adsorption energy and short $0-0$ bond length indicate that $\mathrm{O}_{2}$ molecules are difficult to activate on oxidized g-Pt $t_{1}$ sites, which explains the poor ORR activity of $\mathrm{Pt}_{1} / \mathrm{C}$, inferior to pure $\mathrm{N}$-doped carbon.

After comprehensive experimental characterization and theoretical calculations, it was ultimately concluded that single $\mathrm{Pt}$ atom anchored on single pyridinic $\mathrm{N}$ was the main active site for ORR [6]. Specifically, the presence of single Pt atoms as the major components was also experimentally identified in pure carbon supports $\left(\mathrm{Pt}_{1} / \mathrm{C}\right)$ [6]. Note that pure carbon black contains intrinsic defects, and N-doping probably enables the creation of more defects on carbon. Another scenario, which we propose here, is that defects on carbon may be true anchoring sites for Pt single atoms, in addition to the previously proposed $\mathrm{N}$-doped sites.

Another recent report [7] reinforces the viewpoint that defects in carbon can anchor SMAs, thus promoting ORR. An atomic-level insight into M-C-N catalysts, with direct visualization of the proposed ORR active sites (N-coordinated Fe atoms $\left(\mathrm{FeN}_{4}\right)$ embedded in carbon), was obtained by low-voltage aberration-corrected scanning transmission electron microscopy (AC-STEM) [7]. Individual Fe atoms embedded in a few-layer 

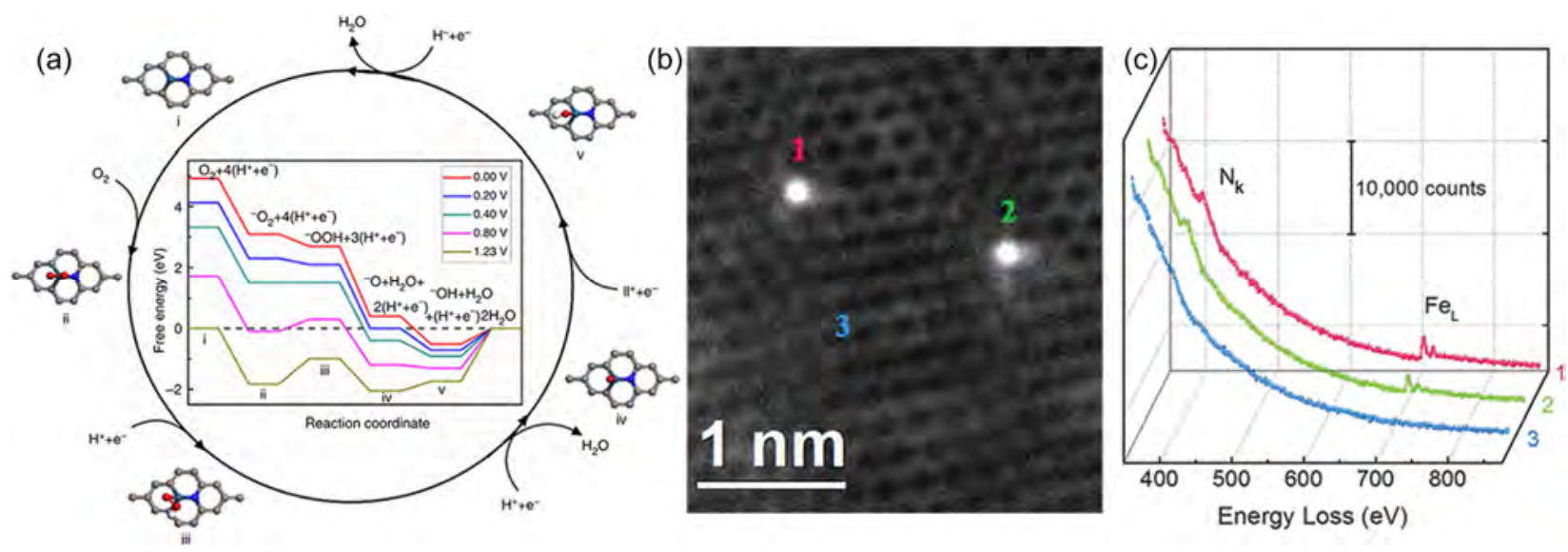

Fig. 1. (a) The proposed ORR pathways on g-Pt $t_{1}-\mathrm{N} / \mathrm{C}$. Inset: the corresponding free energy diagram for ORR, reprinted from Ref. [6]; (b) HAADF-STEM image of Fe-C-N samples: the labels 1 and 2 are individual Fe atoms while 3 is pure few-layer graphene; (c) EELS of N K-edge $\left(\mathrm{N}_{\mathrm{K}}\right)$ and $\mathrm{Fe}$ L-edge $\left(\mathrm{Fe}_{\mathrm{L}}\right)$ obtained from 1, 2 and 3. (b) and (c) reprinted from Ref. [7].

graphene sheet were observed by high-angle annular dark-field (HAADF)-STEM (Fig. 1(b)). Electron energy-loss spectroscopy (EELS) demonstrated the presence of $\mathrm{N}$ around single $\mathrm{Fe}$ atoms in the bulk regions, as shown in Fig. 1(c), where the $\mathrm{N}$ K-edge only appears around the Fe atom sites and is absent from the Fe-free pure graphene regions. The quantitative $\mathrm{Fe} / \mathrm{N}$ ratio acquired from several sites implied an average composition of $\mathrm{FeN}_{4}$ according to the EELS data. Because of the hierarchical pore structure, an abundance of graphite (002) basal-plane edges and steps was found in the catalyst. The single Fe atoms observed by AC-STEM were preferentially positioned at exposed edges and steps, where $\mathrm{N}$ coordination can hardly be verified with STEM-EELS. Nevertheless, the edge-hosted FeN 4 structures satisfy the indirect evidence obtained by Mössbauer, X-ray absorption fine structure and X-ray photoelectron spectroscopies. The concentration of edge-hosted structures is higher than the bulk-hosted sites. Quantum chemistry calculations demonstrated that the $\mathrm{FeN}_{4}$ sites follow different ORR pathways, in terms of their hosting sites, at the edge or in the bulk of graphene. Since the edge-hosted $\mathrm{FeN}_{4}$ sites in a fuel cell can be spontaneously ligated by $\mathrm{OH}^{-}$, the highly ORR-active structure gives credit to the key involvement of edge-hosted $\mathrm{FeN}_{4}$ sites [7].

In fact, since most Fe atoms are positioned at the edges and steps, whether they are only associated with N-doped sites, remains an open question. Undoubtedly, the edges and steps in carbon-based materials are usually cataloged as defects. Since the Fe-N ligands cannot be detected directly in the edges and steps [7], another likely possibility cannot be excluded: single Fe atoms may be anchored by various other defects, such as vacancies, dislocations and grain boundaries (Fig. 2), rather than the proposed $\mathrm{N}$ sites in carbon.

Taking all these inferences into account, it is completely possible that various defects, rather than the only candidate of $\mathrm{N}$-doped sites, are true anchoring sites for SMAs. That is, grain boundaries, dislocations and other point defects, such as B, P, S, and $\mathrm{F}$ atoms doped in carbon, can also serve as anchoring sites for SMAs, as shown in Fig. 2. The defects may induce variations of bond length, valence state, and modulation of the surface electronic structure of neighboring carbon atoms, and consequently enable trapping of SMAs. Careful synthesis and the ability to discern various defects are undoubtedly crucial for preparing SMA-anchoring materials. The suggested detection methods for each defect are shown at the bottom of Fig. 2 accordingly. The delicate design of defects on carbon supports probably presents a general route to SMA anchoring. If this assumption holds, it should provide a new approach to the preparation of SMA catalysts for improved ORR performance. In addition, it remains challenging to identify various crucial factors in the mechanism of carbon-based SMA catalysts for $4 \mathrm{e}^{-}$ ORR (Fig. 2), as other possible active sites have also been pro-

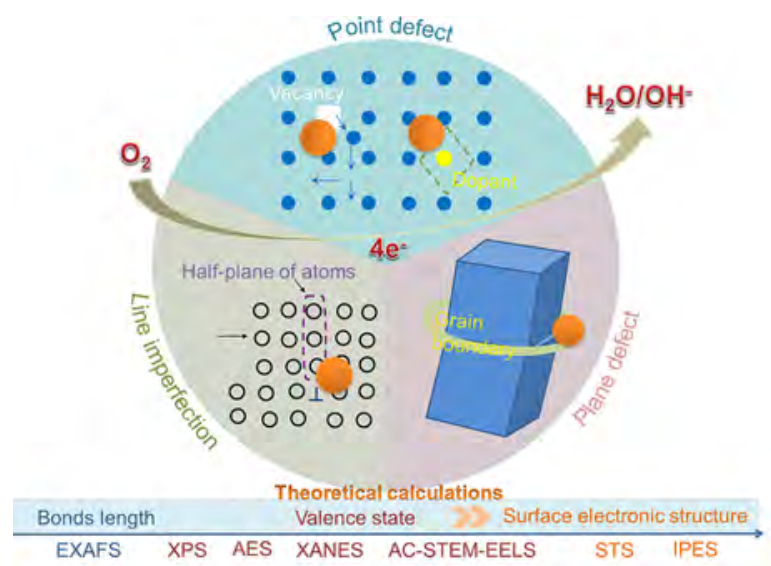

Fig. 2. Three types of common defects. Based on geometrical considerations, all three defect types can serve as anchoring sites for SMAs. All of the resulting defect-anchored single atoms can work as active sites for a $4 \mathrm{e}^{-} \mathrm{ORR}$, directly converting $\mathrm{O}_{2}$ to $\mathrm{H}_{2} \mathrm{O}$ (acidic solution) or $\mathrm{OH}^{-}$ (alkaline solution). The defect-induced variations of bond length, valence state, and modulation of surface electronic structure can be detected by X-ray absorption fine structure spectroscopy (EXAFS), X-ray photoelectron spectroscopy (XPS), Auger electron spectroscopy (AES), X-ray absorption near edge structure spectroscopy (XANES), AC-STEM-EELS, scanning tunneling spectroscopy (STS) and inverse photoelectron spectroscopy (IPES), as well as combinations of these. Theoretical calculations may also provide valuable insights into the SMA-anchoring ability of various defects, and the ultimate impact on ORR. The golden ball represents an SMA. 
posed [8]. Typically, carbon atoms with Lewis basicity adjacent to pyridinic $\mathrm{N}$, instead of the $\mathrm{N}$ atoms themselves, turn out to be ORR active sites in metal-free $\mathrm{N}$-doped carbon materials [9]. Defects in nanocarbons have also been discerned as playing an active role in ORR [10-12]. Therefore, the authentic mechanism of active sites in carbon-based ORR catalysts are not yet clear. We have outlined a new viewpoint, that is, defect-anchored SMAs can serve as active centers in carbon for ORR. Their occurrence probably accounts for the excellent ORR activity of such materials. The microporous nature of zeolites may contribute to the generality of SMA catalysts [13]. In fact, most such catalysts are somewhat versatile, catalyzing not just one reaction but several. Thus, in our view, the use of defects in carbon to trap SMAs for enhanced ORR activity may become a universal strategy in electrocatalysis.

In summary, two excellent recent works by Liu et al. [6] and Chung et al. [7] demonstrated that single Pt or Fe atoms can be effectively anchored on N-doped carbon. These carbon-based single atom catalysts exhibit excellent ORR performance, which is attributed to the active centers: SMAs, anchored by $\mathrm{N}$ dopants. Unfortunately, two facts were not underscored: some SMAs were also found on carbon free of $\mathrm{N}$-doping and these catalysts showed ORR activity as well; most single atoms tend to be sited on the defect-rich edges or steps of the carbon support. This indicates that N-doped sites are not the only candidates for anchoring SMAs. Inspired by the advanced characterization in these two reports $[6,7]$, we put forward that various defects, not just $\mathrm{N}$-doped sites, may be the anchoring sites for SMAs. Thus, cost-effective single atom catalysts for excellent ORR can be probably obtained by delicate design of carbon defects.

\section{Acknowledgments}

Support by the Jilin Province/Jilin University
co-Construction Project-Funds for New Materials (SXGJSF2017-3, Branch-2/440050316A36), the National Key R\&D Program of China (2016YFA0200400), the NSFC (51372095), the Program for JLU Science and Technology Innovative Research Team (JLUSTIRT), "Double-First Class" Discipline for Materials Science \& Engineering, and the Special Funding for Academic Leaders are greatly acknowledged.

\section{Wei Zhang}

a State Key Laboratory of Automotive Simulation and Control, Department of Materials Science, and International Center of Future Science, and Electron Microscopy Center, Jilin University, Changchun 130012, Jilin, China;

b CIC Energigune, Parque Tecnológico de Álava, Albert Einstein 48, Miñano 01510, Spain;

c Ikerbasque, Basque Foundation for Science, Bilbao 48013, Spain

Tel/Fax: +86-431-85167109; weizhang@jlu.edu.cn

Weitao Zheng

a State Key Laboratory of Automotive Simulation and Control, Department of Materials Science, and International Center of Future Science, and Electron Microscopy Center, Jilin University, Changchun 130012, Jilin, China

Tel/Fax: +86-431-85168246; E-mail: wtzheng@jlu.edu.cn

Received 27 September 2017

Accepted 24 October 2017

Published 5 January 2018

DOI: $10.1016 /$ S1872-2067(17)62944-9

\section{References}

[1] M. K. Debe, Nature, 2012, 486, 43-51.

[2] B. T. Qiao, A. Q. Wang, X. F. Yang, L. F. Allard, Z. Jiang, Y. T. Cui, J. Y.

\section{Graphical Abstract}

Chin. J. Catal., 2018, 39: 4-7 doi: 10.1016/S1872-2067(17)62944-9

\section{Pinpointing single metal atom anchoring sites in carbon for oxygen reduction: Doping sites or defects?}

Cai Zhang, Wei Zhang *, Weitao Zheng *

Jilin University, China;

CIC Energigune, Parque Tecnológico de Álava, Spain;

Ikerbasque, Basque Foundation for Science, Spain

Nitrogen species doped in carbon were previously identified as anchoring sites for single Pt/Fe atoms. Some clues, however, imply that various defects, rather than only $\mathrm{N}$-doped sites, can confine single metal atoms, ultimately leading to improved ORR performance.

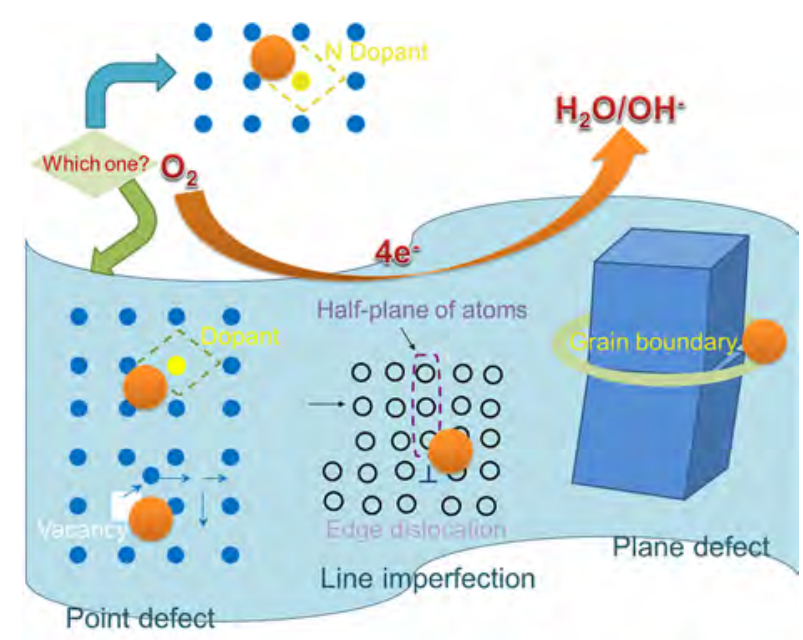


Liu, J. Li, T. Zhang, Nat. Chem., 2011, 3, 634-641.

[3] B. Han, R. Lang, B. T. Qiao, A. Q. Wang, T. Zhang, Chin. J. Catal., 2017, 38, 1498-1507.

[4] T. Deng, W. T. Zheng, W. Zhang, Chin. J. Catal., 2017, 38, 1489-1497.

[5] W. Zhang, W. T. Zheng, Adv. Funct. Mater., 2016, 26, 2988-2993.

[6] J. Liu, M. Q. Jiao, L. L. Lu, H. M. Barkholtz, Y. P. Li, Y. Wang, L. H. Jiang, Z. J. Wu, D. J. Liu, L. Zhuang, C. Ma, J. Zeng, B. S. Zhang, D. S. Su, P. Song, W. Xing, W. L. Xu, Y. Wang, Z. Jiang, G. Q. Sun, Nat. Commun., 2017, 8, 15938.

[7] H. T. Chung, D. A. Cullen, D. Higgins, B. T. Sneed, E. F. Holby, K. L. More, P. Zelenay, Science, 2017, 357, 479-484.
[8] K. H. Wu, D. W. Wang, D. S. Su, I. R. Gentle, ChemSusChem, 2015, 8, 2772-2788.

[9] D. H. Guo, R. Shibuya, C. Akiba, S. Saji, T. Kondo, J. Nakamura, Science, 2016, 351, 361-365.

[10] C. Tang, H. F. Wang, X. Chen, B. Q. Li, T. Z. Hou, B. S. Zhang, Q. Zhang, M. M. Titirici, F. Wei, Adv. Mater., 2016, 28, 6845-6851.

[11] C. Tang, Q. Zhang, Adv. Mater., 2017, 29, 1604103.

[12] D. F. Yan, Y. X. Li, J. Huo, R. Chen, L. M. Dai, S. Y. Wang, Adv. Mater., 2017, 29, 1606459.

[13] J. Zhang, L. Wang, Y. Shao, Y. Q. Wang, B. C. Gates, F. S. Xiao, Angew. Chem. Int. Ed., 2017, 56, 9747-9751.

\title{
掺杂位点与缺陷, 谁是金属单原子在碳材料中的针固位点及氧还原的活性中心?
}

\author{
张 彩 ${ }^{\mathrm{a}}$, 张 伟 ${ }^{\mathrm{a}, \mathrm{b}, \mathrm{c}, *}$, 郑伟涛 ${ }^{\mathrm{a}, \#}$ \\ a 吉林大学汽车仿真与控制国家重点实验室和材料科学与工程学院和未来科学国际合作实验室和吉林大学电镜中心, \\ 吉林长春130012, 中国 \\ b西班牙能源协作研究中心, 阿拉瓦01510, 西班牙 \\ ‘西班牙巴斯克科学基金会, 毕尔巴鄂48013, 西班牙
}

摘要: 为了改善燃料电池阴极氧还原反应缓滞的动力学特征, 高效的催化剂亟待被开发. 金属单原子催化剂能够提高金属 的利用率, 降低催化剂的成本, 很好地平衡了性能和价格的关系, 从而使其作为燃料电池阴极催化剂具有广泛的应用前景. 最近有两篇优秀的工作报道了关于金属单原子催化剂在氧还原反应中的应用. 其中一篇是Liu等制备了铂单原子负载于氮 掺杂的碳黑, 这种催化剂表现出了很好的氧还原催化活性. 通过完整的实验与理论研究, 证明了铂单原子被吡啶氮针固的 结构是催化氧还原反应的活性中心. 在该工作的对比样品中, 我们注意到铂负载于没有进行氮掺杂的碳黑上, 依旧有相当 大数量的铂单原子存在, 该催化剂亦表现出了较好的催化活性. 考虑到碳黑本身存在有大量的缺陷, 且氮的掺杂提高了碳 黑中的缺陷数量, 这是更多的单原子铂存在于氮掺杂的碳黑上的根本原因. 因此, 不只氮掺杂位点能够针固铂单原子, 碳 黑中存在的其他缺陷也很可能具有类似作用, 这些因素的共同作用导致了最终的较高氧还原催化活性.

另外一篇报道也印证了此观点. Chung等使用低压球差矫正扫描透射电子显微镜直接探测到了氧还原的催化活性位: 铁与四个氮配位结构 $\left(\mathrm{FeN}_{4}\right)$. 他们通过高角环形暗场像观察到铁单原子, 配合电子能量损失谱检测到氮元素只存在于铁单 原子周围, 通过多次实验取平均, 证明了 $\mathrm{FeN}_{4}$ 结构的存在. 但该报道明确说明了大量的铁单原子事实上存在于暴露的边缘 和褶皱阶梯处, 而这些位置很容易被电子束损伤, 即便是先进的低压球差电镜也难以观察到. 虽然利用其它多种间接的表 征手段佐证了 $\mathrm{FeN}_{4}$ 结构的存在, 但这并不能排除其它可能性. 众所周知, 边缘和阶梯处存在着大量的缺陷, 如空位、位错等. 因此, 不只是氮掺杂位, 多种缺陷都可能是铁单原子的真正针固位点, 并最终对氧还原反应起到协同催化作用.

充分阐明碳基单原子氧还原催化剂催化活性位的本质有助于高效的、成本低廉的燃料电池阴极材料的优化设计. 总 的来说, 不只氮掺杂位点, 其他多种缺陷如空位、位错等也很可能在针固金属单原子中起作用且最终有利于氧还原反应顺 利进行. 合理的对碳材料进行缺陷设计很可能是制备高效碳基金属单原子催化剂的最优方案.

关键词: 金属单原子; 氮掺杂碳; 针固位; 缺陷; 氧还原反应

收稿日期: 2017-09-27. 接受日期: 2017-10-24. 出版日期: 2018-01-05.

*通讯联系人. 电话/传真: (0431) 85167109; 电子信箱: weizhang@jlu.edu.cn

\#通讯联系人. 电话/传真: (0431)85168246; 电子信箱: wtzheng@jlu.edu.cn

基金来源：国家重点研发计划纳米专项(2016YFA0200400); 国家自然科学基金(51372095); 吉林省省校共建项目-新材料专项 (SXGJSF2017-3, 子课题2/440050316A36); 吉林大学科技创新团队; 吉林大学双一流学科; 吉林大学学术带头人专项基金. 本文的电子版全文由Elsevier出版社在ScienceDirect上出版(http://www.sciencedirect.com/science/journal/18722067). 